\title{
Seasonal variability of Saharan desert dust and ice nucleating particles over Europe
}

\author{
L. B. Hande ${ }^{1}$, C. Engler ${ }^{2}$, C. Hoose ${ }^{1}$, and I. Tegen ${ }^{2}$ \\ ${ }^{1}$ Karlsruhe Institute of Technology, Karlsruhe, Germany \\ ${ }^{2}$ Leibniz-Institute for Tropospheric Research, Leipzig, Germany \\ Correspondence to: L. B. Hande (luke.hande@kit.edu)
}

Received: 10 November 2014 - Published in Atmos. Chem. Phys. Discuss.: 19 December 2014

Revised: 9 April 2015 - Accepted: 10 April 2015 - Published: 30 April 2015

\begin{abstract}
Dust aerosols are thought to be the main contributor to atmospheric ice nucleation. While there are case studies supporting this, a climatological sense of the importance of dust to atmospheric ice nucleating particle (INP) concentrations and its seasonal variability over Europe is lacking. Here, we use a mesoscale model to estimate Saharan dust concentrations over Europe in 2008. There are large differences in median dust concentrations between seasons, with the highest concentrations and highest variability in the lower to mid-troposphere. Laboratory-based ice nucleation parameterisations are applied to these simulated dust number concentrations to calculate the potential INP resulting from immersion freezing and deposition nucleation on these dust particles. The potential INP concentrations increase exponentially with height due to decreasing temperatures in the lower and mid-troposphere. When the ice-activated fraction increases sufficiently, INP concentrations follow the dust particle concentrations. The potential INP profiles exhibit similarly large differences between seasons, with the highest concentrations in spring (median potential immersion INP concentrations nearly $10^{5} \mathrm{~m}^{-3}$, median potential deposition INP concentrations at $120 \%$ relative humidity with respect to ice over $10^{5} \mathrm{~m}^{-3}$ ), about an order of magnitude larger than those in summer. Using these results, a best-fit function is provided to estimate the potential INPs for use in limited-area models, which is representative of the normal background INP concentrations over Europe. A statistical evaluation of the results against field and laboratory measurements indicates that the INP concentrations are in close agreement with observations.
\end{abstract}

\section{Introduction}

Atmospheric aerosols have an important influence on cloud properties through the direct and indirect aerosol effects, however there is significant uncertainty in quantifying both of these. Considering only the indirect effects, the ice phase has a particularly strong influence on cloud properties by affecting cloud lifetime and precipitation processes (Lohmann and Feichter, 2005; Boucher et al., 2013). The ice nucleating ability of many aerosols has been experimentally determined through both field (e.g. Cozic et al., 2008; Conen et al., 2012; Joly et al., 2014) and laboratory studies (Hoose and Möhler, 2012; Murray et al., 2012). Mineral dust has been identified as a major contributor to atmospheric ice nucleation at temperatures relevant for mixed phase and cirrus clouds (Heintzenberg et al., 1996; DeMott et al., 2003; Atkinson et al., 2013). During large Saharan dust outbreaks, model results suggest that dust aerosol concentrations can reach $10^{7} \mathrm{~m}^{-3}$ over Europe (Bangert et al., 2012), but it also appears that dust dominates the normal background ice nucleating particle (INP) and ice residual composition in the absence of these large dust events (Targino et al., 2006; Prenni et al., 2009; Kamphus et al., 2010; Cziczo et al., 2013). This lends some weight to the notion that dust can have an important indirect effect on clouds (Sassen, 2002; Sassen et al., 2003) on seasonal timescales.

Other important ice-nucleating aerosols are soot and biological particles (Pratt et al., 2009), however their contribution to ice nucleation is on average lower than that of dust (Hoose et al., 2010). Case studies of the impact of dust events on INP concentrations in Europe have been performed (Klein et al., 2010; Chou et al., 2011; Mamouri and Ansmann, 2015); however, climatological estimates of dust number concentrations and the resulting INP concentrations, as 
well as an understanding of their seasonal variability, remain elusive.

Ice nucleation in the atmosphere takes place via four different pathways: immersion, condensation, deposition, and contact freezing. Efforts to parameterise these processes for use in models have relied on either empirical evidence or a theoretical approach, yielding a wide variety of parameterisations (e.g. Fletcher, 1962; Cooper, 1986; Meyers et al., 1992; Phillips et al., 2008; DeMott et al., 2010). Typically, these parameterisations are independent of the aerosol type, however more recently, dust-aerosol-specific parameterisations have begun to emerge (Niemand et al., 2012; Steinke et al., 2014; DeMott et al., 2014; Hiranuma et al., 2014).

The aims of this paper are straightforward. Firstly, we will quantify the background dust number concentrations in Europe during different seasons using model data from December 2007 to August 2008. This will allow the quantification of the potential INP concentrations resulting from immersion freezing and deposition nucleation on these particles, using two new parameterisations specific to dust aerosols. These results will then be used to develop a best-fit function which can be used to estimate immersion and deposition INP concentrations in regional climate and numerical weather prediction models, and for process studies. Finally, a statistical comparison with available observations will be presented.

\section{Saharan dust and INP concentrations}

The COnsortium for Small-scale MOdelling (COSMO) (Steppeler et al., 2003) meteorological model coupled to the MUlti-Scale Chemistry Aerosol Transport (MUSCAT) (Wolke et al., 2004) was used to simulate the generation and transport of Saharan desert dust to Europe for the period December 2007-August 2008. The model was configured to simulate dust in five size bins $(0.1-0.3,0.3-0.9,0.9-$ 2.6, 2.6-7.9, 7.9-24 $\mu \mathrm{m})$. The dust model uses a horizontal grid resolution of $28 \mathrm{~km}$ and 40 vertical layers. Dust emission fluxes depend on surface wind friction velocities, surface roughness, soil particle size distribution, and soil moisture in unvegetated areas (Tegen et al., 2002). While soil temperature is not directly included in the dust emission scheme, snow-covered grid cells are excluded as dust sources. Transported dust from the Sahara (which are the focus of this study) are considered to be the main source for INPs. Local soil dust sources are considered less important, as their emission fluxes are low and they generally remain in the boundary layer.

Dust advection is computed by a third-order upstream scheme; particle removal is computed considering dry and wet deposition processes. COSMO simulations were initialised with analysis fields from the global model GME (Global Model of the DWD) and the lateral boundary conditions updated 6-hourly. The simulations were re-initialised every $48 \mathrm{~h}$ to keep the modelled meteorology close to the analysis fields. The model results have been extensively evaluated with field measurements of ground-based and airborne measurements of dust concentrations as well as size distribution, aerosol optical thickness and lidar backscatter and extinction (Heinold et al., 2009, 2011; Tegen et al., 2013). The evaluation of the dust model results shown in Tegen et al. (2013) were performed with the same model setup as described in this work. It performed well in a regional model intercomparison of an observed event in the Bodélé depression in Chad (Todd et al., 2008).

The simulated dust number concentrations were used to estimate the potential immersion and deposition INP concentrations. Niemand et al. (2012) provides a parameterisation for immersion freezing on natural dust particles. This work is derived from experiments on a variety of dust types carried out at the Aerosol Interaction and Dynamics in the Atmosphere (AIDA) cloud chamber facility, and is valid between temperatures of $261.15-237.15 \mathrm{~K}$ at or above water saturation. The parameterisation is a function of the dust particle surface area and the temperature. Similarly, a parameterisation for deposition freezing on Arizona Test Dust was experimentally determined by Steinke et al. (2014) from AIDA measurements. This parameterisation is active at colder temperatures of between $253-220 \mathrm{~K}$, and above ice supersaturation. While there are indications that Arizona Test Dust is a more efficient ice nucleus than natural desert dust particles at the higher end of this temperature range, their behaviour is comparable at temperatures below $238 \mathrm{~K}$ (Hoose and Möhler, 2012; Murray et al., 2012), i.e. in the cirrus regime where deposition nucleation is most relevant. At present, a comparable parameterisation based on laboratory experiments for natural desert dusts covering the entire required temperature and humidity range is not available.

The potential immersion INP concentration is simply the parameterised immersion INP concentration irrespective of the relative humidity with respect to water. Similarly, the potential deposition INP concentrations are calculated from the simulated dust concentrations and the parameterisation from Steinke et al. (2014) at a prescribed relative humidity with respect to ice $\left(\mathrm{RH}_{\text {ice }}\right)$, irrespective of the actual in situ $\mathrm{RH}_{\text {icee }}$. The ambient temperature in each model grid box was used for the calculation of potential INPs, and only if the temperature was within the range of the relevant parameterisation. The potential immersion and deposition INP concentrations are presented here in order to be independent of the resolved and parameterised clouds in COSMO-MUSCAT. This concept of potential INP has been used previously by others (Murray et al., 2012). The domain considered here is over central Europe, between $44-60^{\circ} \mathrm{N}$ and $0-20^{\circ} \mathrm{E}$.

Figure 1 shows the horizontal median, the 5th and 95th percentiles for total dust number concentration, total dust surface area, and the parameterised potential immersion and deposition INP concentrations for all seasons of 2008. The winter season refers to December 2007, January and February 2008, spring comprises March to May of 2008, summer 

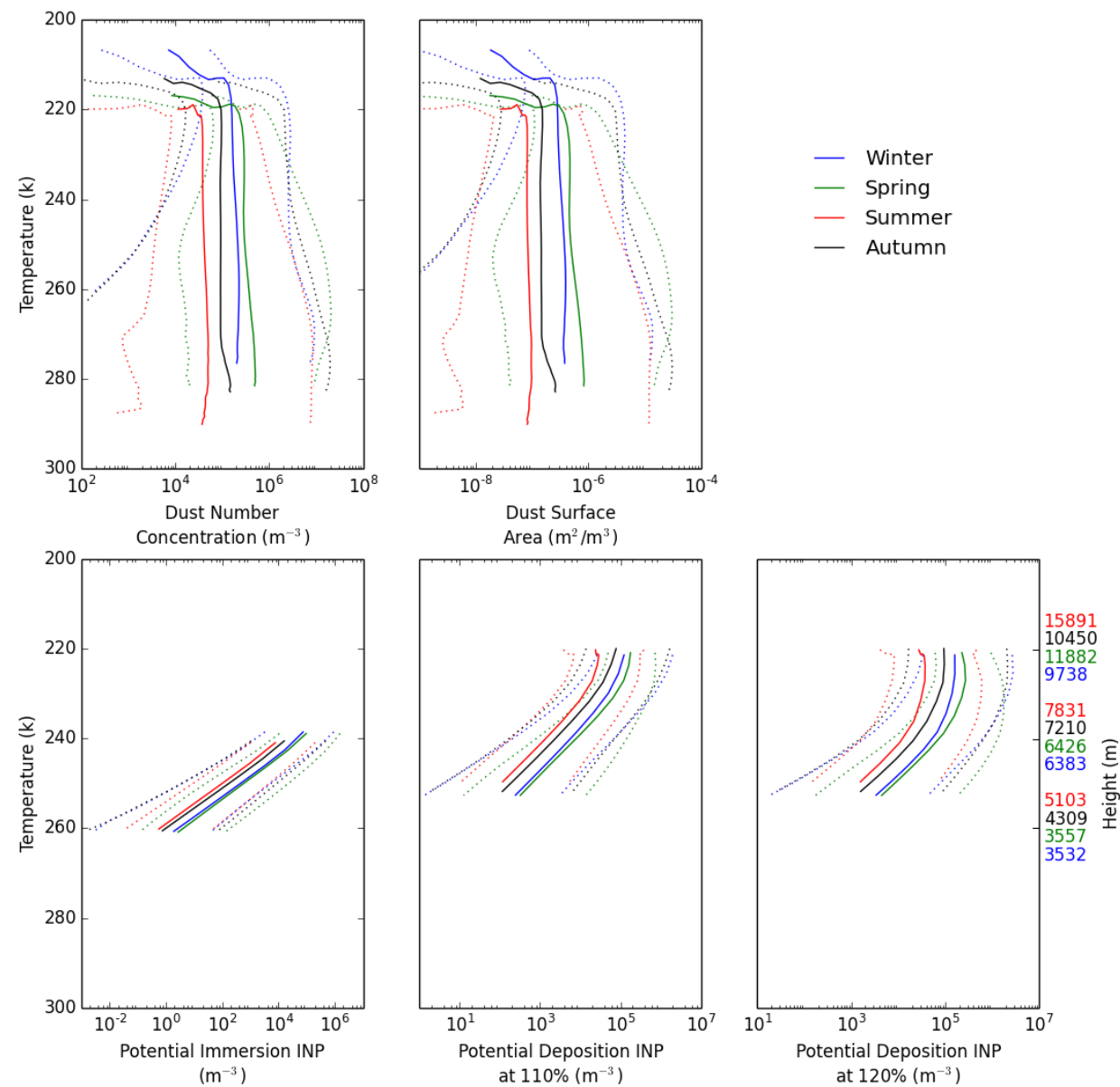

Figure 1. Median (solid), 5th and 95th percentiles (dotted) for total dust number concentration, total dust surface area, potential immersion INP, and potential deposition INP at $\mathrm{RH}_{\text {ice }}$ of 110 and $120 \%$ over Europe (44-60 $\mathrm{N}$ and $0-20^{\circ} \mathrm{E}$ ) for winter (blue), spring (green), summer (red) and autumn (black). The Niemand et al. (2012) parameterisation is valid between 237.15-261.15 K, and the Steinke et al. (2014) parameterisation is valid from $220-253 \mathrm{~K}$.

comprises June to August 2008, and finally autumn refers to September to November 2008. The potential deposition INP concentrations are calculated using a constant $\mathrm{RH}_{\text {ice }}$ of $110 \%$. To account for a range of possible in cloud relative humidities, potential deposition nucleation is also shown at $120 \%$.

The dust number concentration statistics were firstly computed for a whole month. Then, in order to calculate seasonal (yearly) statistics, the monthly statistics were averaged over a 3 (12) month period. Using this, the dust surface area statistics were calculated by assuming spherical particles with the bin centre radius. The INP statistics were then calculated by using the respective dust number concentration statistic as an input to the parameterisation, along with the mean temperature for that season.

Qualitatively, the dust surface area and the dust number concentrations have similar vertical profiles, which implies there is no significant change in the size distribution with height. The dust number concentrations differ largely be- tween seasons, with median values in spring around $3 \times$ $10^{5} \mathrm{~m}^{-3}$, and in summer about an order of magnitude less. These concentrations decrease by between $25 \%$ during summer, to $45 \%$ during spring from the lower troposphere to the tropopause, and there is the largest amount of variability in dust concentrations in the lower to mid-troposphere. The mean values of dust are 25 times larger than the median values in summer, 5 times larger in spring, and 17 and 7 times larger for autumn and winter respectively. This implies that infrequent but significant dust events are a major contributor to the mean values.

Looking at the more extreme values, the maximum in the 95th percentile of the dust number concentration is around $2 \times 10^{7} \mathrm{~m}^{-3}$ at around $265 \mathrm{~K}$. This is the same as the modelled concentrations of over $10^{7} \mathrm{~m}^{-3}$ reported by Bangert et al. (2012) during a significant Saharan dust event of May 2008. Therefore, the 95th percentile of dust number concentrations is a good approximation for the concentration during a large Saharan dust outbreak. 

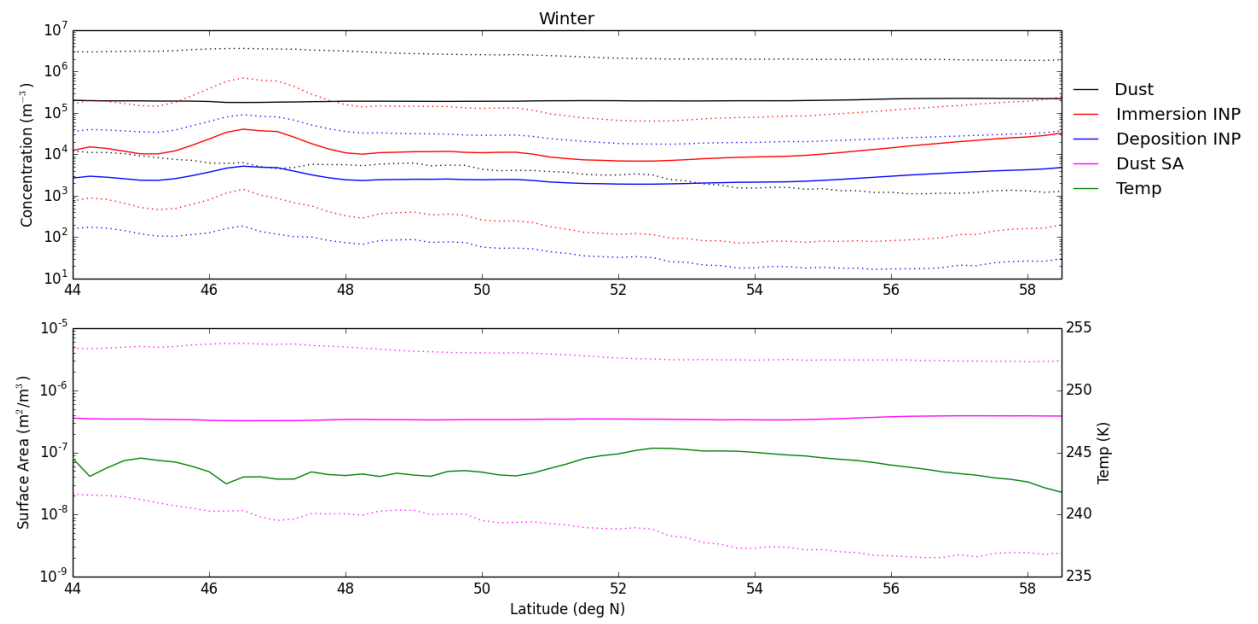

Figure 2. Top panel: median (solid), 5th and 95th percentiles (dotted) for total dust number concentration (black), potential immersion INP (red), and potential deposition INP at $110 \%$ (blue) at $6 \mathrm{~km}$ above terrain over Europe for winter. Bottom panel: median (solid) and mean (dashed) total dust surface area (magenta) and temperature (green). Note that the Alpine regions are in a range about $46-48^{\circ} \mathrm{N}$.

These dust number concentrations translate into maximum median potential INP concentrations in the immersion mode of $9.5 \times 10^{4} \mathrm{~m}^{-3}$ at $239 \mathrm{~K}$. The summertime maximum concentration is just over $7.6 \times 10^{3} \mathrm{~m}^{-3}$ at the coldest temperatures allowed by the parameterisation. The area bounded by the 5th and 95th percentiles spans more than an order of magnitude for all seasons. The concentrations of immersion INPs increase exponentially for all seasons, until the limiting temperature of $237.15 \mathrm{~K}$ is reached.

In the deposition mode, median potential INP concentrations at $\mathrm{RH}_{\text {ice }}$ of $110 \%$ are over $1 \times 10^{5} \mathrm{~m}^{-3}$ during spring. The summertime maximum is around $2.8 \times 10^{4} \mathrm{~m}^{-3}$. The 5 th and 95th percentiles indicate slightly less variability in the deposition mode for both seasons. As temperatures decrease, the concentrations increase exponentially until the ice activated fraction increases sufficiently to limit INP production. This normally occurs at temperatures colder than $230 \mathrm{~K}$ for all seasons.

The final panel in Fig. 1 shows potential deposition INP concentrations at $\mathrm{RH}_{\text {ice }}$ of $120 \%$. Here, the profiles closely resemble the potential deposition INP at $110 \%$, but just shifted to higher concentrations. There is a slight change in the shape of the profile, since more INPs can activate at a given temperature for the higher $\mathrm{RH}_{\text {ice }}$ conditions. Now the maximum median concentrations are on average more than double those at $110 \%$.

The maximum in the mean concentrations in the immersion mode are an order of magnitude larger than the maximum median concentrations for summer. The difference is less in the deposition mode. Again, this suggests that the mean concentrations are dominated by a few very significant events of large INP concentrations.

Figure 2 shows the median, 5th and 95th percentiles for the meridionally averaged total dust number concentration, potential immersion, and potential deposition INP concentrations, as a function of latitude and at an altitude of $6 \mathrm{~km}$ above the terrain during winter, which is where most INPs are located. The bottom panel also shows total dust surface area, and temperature at $6 \mathrm{~km}$. The dust concentrations and total surface area are remarkably constant with increasing latitude. The bottom panel shows some variability in temperature. There is about a $2 \mathrm{~K}$ drop in temperature over the high Alpine regions around $47^{\circ} \mathrm{N}$, and another decrease in temperature north of $53^{\circ} \mathrm{N}$. This means that there is an amplification of INP concentrations in these colder regions. In the immersion mode, median potential concentrations change from a maximum of $4 \times 10^{4}$ over the high terrain, down to $1 \times 10^{4} \mathrm{~m}^{-3}$ a few degrees further north, and then increase again to about $3 \times 10^{4} \mathrm{~m}^{-3}$ at the northernmost point of the domain. A similar change occurs in the deposition mode, with maximum and minimum median potential concentrations of $1 \times 10^{5}$ and $2 \times 10^{3} \mathrm{~m}^{-3}$ respectively.

The variability of dust and INP as a function of longitude was also investigated, and a similarly small amount of variability was found (not shown). In the immersion mode, an enhancement in the median INP concentrations from about 1500 to $7000 \mathrm{~m}^{-3}$ was found around $7^{\circ} \mathrm{E}$. This corresponds to a decrease in temperature of about $3^{\circ}$ at the western edge of the Alps. This implies that the potential immersion and deposition vertical profiles presented in Fig. 1 are a suitable representation of INP concentrations over the whole domain considered here.

The shape of the median INP profiles in Fig. 1 shows an exponential increase until the ice-activated fraction increases sufficiently, at which time the concentrations begin to follow that of the dust. Therefore, the median profiles can be 
described by the following function:

$C_{\mathrm{INP}}\left(T_{\mathrm{K}}\right)=A \times \exp \left[-B \times\left(T_{\mathrm{K}}-T_{\min }\right)^{C}\right]$.

$T_{\mathrm{K}}$ is the model temperature in Kelvin, and the free parameters are defined in Table 1 for each case of potential immersion and potential deposition INPs in each season, as well as for the whole year. Using Eq. (1) along with these parameters, it is possible to specify realistic median INP concentrations for model simulations over Europe. This new parameterisation must only be applied to within the temperature range specified by $T_{\min }$ and $T_{\max }$ in order to prevent unrealistically high concentrations at very cold temperatures. Since the parameterisation uses the median concentrations, it is representative of the normal background INP concentrations. An analysis of the residuals showed that during a large dust event, INPs are produced at high concentrations over all temperatures compared to a non-dust event, therefore the mean concentrations are not used here since these would be heavily influenced by large dust outbreaks. However, for sensitivity studies wishing to investigate the impact of large or small background INP concentrations, scaling factors for the 5th and 95th percentiles (5th PSF and 95th PSF) are provided. Using these, the concentrations given by Eq. (1) can be simply scaled to higher and lower concentrations. The model-diagnosed moisture or the parameterised cloud occurrence must be used to define supersaturated conditions with respect to water for immersion INPs, and with respect to ice for deposition INPs. Finally, it is recommended to use $C_{\mathrm{INP}}(273.15)$ for temperatures colder than $273.15 \mathrm{~K}$ for immersion freezing, and $C_{\mathrm{INP}}(220)$ for temperatures colder than $220 \mathrm{~K}$ for deposition nucleation, in order to prevent zero ice nuclei concentrations.

Since the Steinke et al. (2014) parameterisation is a function of both temperature and supersaturation, the deposition nucleation parameterisation provided here can be simply scaled to the model-diagnosed $\mathrm{RH}_{\text {ice }}$. A deposition scaling factor (DSF) was defined as the ratio of mean deposition INPs at a given $\mathrm{RH}_{\text {ice }}$ to the mean deposition INPs at $\mathrm{RH}_{\text {ice }}=110 \%$, and calculated from the model data for $\mathrm{RH}_{\text {ice }}$ from 100 to $145 \%$. This showed an increase in mean deposition concentrations that followed the form

$\operatorname{DSF}\left(\mathrm{RH}_{\text {ice }}\right)=a \times \arctan \left(b \times\left(\mathrm{RH}_{\text {ice }}-100\right)+c\right)+d$,

where $a=2.7626, \quad b=0.0621, \quad c=-1.3107$ and $d=$ 2.6789 , which were determined by a best fit. Finally, the scaled INP concentrations due to deposition nucleation, are approximately

$C_{\mathrm{INP}}\left(T_{\mathrm{K}}, \mathrm{RH}_{\text {ice }}\right) \approx C_{\mathrm{INP}}\left(T_{\mathrm{K}}\right) \times \operatorname{DSF}\left(\mathrm{RH}_{\text {ice }}\right)$,

where $C_{\mathrm{INP}}\left(T_{\mathrm{K}}\right)$ is the concentration of deposition INPs at $\mathrm{RH}_{\text {ice }}=110 \%$, given by Eq. (1), and the approximation is most valid for small activated fractions.

Figure 3 shows the INP concentrations derived from Eqs. (1) and (3) at $\mathrm{RH}_{\text {ice }}=101 \%$ and $120 \%$, compared to
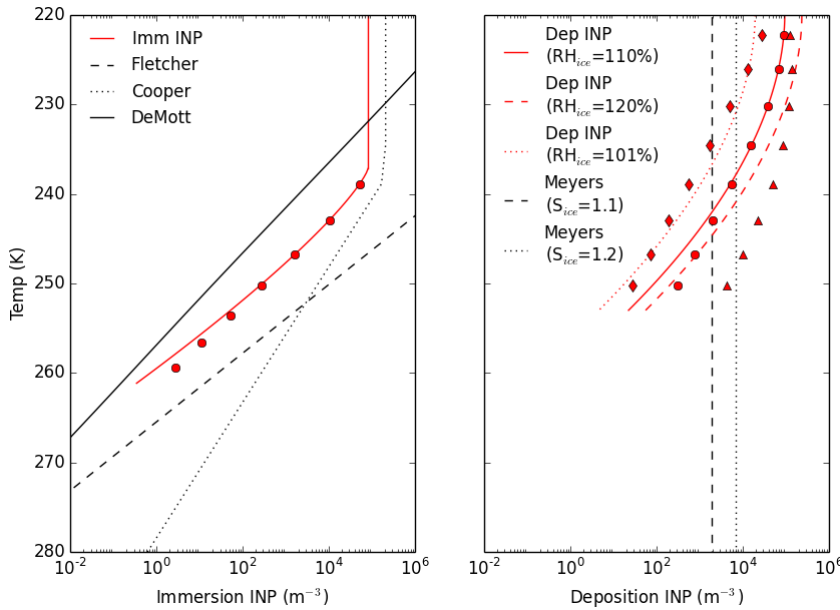

Figure 3. Left: immersion INP concentrations from Eq. (1) using yearly parameters (red). The red circles represent the model data. The black dashed line is the Fletcher (1962) parameterisation, the dotted line represents the Cooper (1986) parameterisation, and the solid line represents DeMott et al. (2014) parameterisation. Right: deposition INP from Eq. (3) using yearly parameters (red), at $\mathrm{RH}_{\text {ice }}=110 \%$ (solid), $\mathrm{RH}_{\text {ice }}=120 \%$ (dashed) and $\mathrm{RH}_{\text {ice }}=$ $101 \%$ (dotted). The black vertical dashed (dotted) line represents concentrations from Meyers et al. (1992) at $S_{\text {ice }}=1.1\left(S_{\text {ice }}=1.2\right)$. The red circles (diamonds/triangles) represent the model data at $\mathrm{RH}_{\text {ice }}=110 \%\left(\mathrm{RH}_{\text {ice }}=101 \% / 120 \%\right)$.

the Meyers et al. (1992) parameterisation for deposition nucleation, and the Fletcher (1962), Cooper (1986) and DeMott et al. (2014) parameterisations for immersion freezing. For the immersion parameterisations, the mean yearly temperature was used, as well as the yearly dust concentrations for DeMott et al. (2014).

For immersion freezing, the yearly INP concentrations presented here lie nicely in the middle of the other three parameterisations. The concentrations shown here are typically more than an order of magnitude lower than those suggested by Fletcher (1962) or Cooper (1986), and higher than the DeMott et al. (2014) parameterisation by a similar amount. The red circles indicate the model data used in this work, and this demonstrates the high quality of the parameterisation developed here. There is a slight overestimation of INPs at the warmest temperatures, however this is significantly less than the difference between the different parameterisations shown. Note that at temperatures colder than $237.15 \mathrm{~K}$, a constant INP concentration should be used.

The Meyers et al. (1992) deposition parameterisation is a function of supersaturation with respect to ice, therefore the INP concentrations resulting from nucleation at supersaturation of 1.1 (1.2) is shown as the dashed (dotted) line. This is in broad agreement with the mean concentrations from the new estimates presented here. Calculating INP concentrations from Eqs. (1) and (3) has the advantage of capturing seasonal variations in dust aerosol concentrations as well as 
Table 1. Parameters defining Eq. (1), for immersion and deposition INP concentrations (at $\mathrm{RH}_{\mathrm{ice}}=110 \%$ ). The percentile scaling factors (PSF) for the 5th and 95th percentiles are provided.

\begin{tabular}{lrrrrrrr}
\hline Immersion & $A\left(\mathrm{~m}^{-3}\right)$ & $B$ & $C$ & $T_{\max }(\mathrm{K})$ & $T_{\min }(\mathrm{K})$ & 5 th PSF & 95th PSF \\
\hline Winter & $1.0259 \times 10^{5}$ & 0.2073 & 1.2873 & 261.15 & 237.15 & 0.04 & 12.06 \\
Spring & $1.5684 \times 10^{5}$ & 0.2466 & 1.2293 & 261.15 & 237.15 & 0.10 & 17.82 \\
Summer & $2.9694 \times 10^{4}$ & 0.2813 & 1.1778 & 261.15 & 237.15 & 0.13 & 27.28 \\
Autumn & $4.9920 \times 10^{4}$ & 0.2622 & 1.2044 & 261.15 & 237.15 & 0.06 & 31.38 \\
Year & $8.1909 \times 10^{4}$ & 0.2290 & 1.2553 & 261.15 & 237.15 & 0.10 & 17.14 \\
\hline Deposition & $A\left(\mathrm{~m}^{-3}\right)$ & $B$ & $C$ & $T_{\max }(\mathrm{K})$ & $T_{\min }(\mathrm{K})$ & 5 th PSF & 95 th PSF \\
\hline Winter & $1.2663 \times 10^{5}$ & 0.0194 & 1.6943 & 253 & 220 & 0.17 & 15.25 \\
Spring & $1.7836 \times 10^{5}$ & 0.0075 & 2.0341 & 253 & 220 & 0.24 & 5.87 \\
Summer & $2.6543 \times 10^{4}$ & 0.0020 & 2.5128 & 253 & 220 & 0.22 & 12.88 \\
Autumn & $7.7167 \times 10^{4}$ & 0.0406 & 1.4705 & 253 & 220 & 0.16 & 22.19 \\
Year & $9.6108 \times 10^{4}$ & 0.0113 & 1.8890 & 253 & 220 & 0.22 & 12.00 \\
\hline
\end{tabular}

temperature, and not overpredicting INPs at colder temperatures.

Finally, Fig. 3 shows that Eq. (3) provides an accurate description of deposition INPs at multiple values of $\mathrm{RH}_{\text {ice }}$. For the higher values of $\mathrm{RH}_{\text {ice }}$ there is an underestimate at warmer temperatures, since INPs activate more readily under these conditions. However, at lower $\mathrm{RH}_{\text {ice }}$ conditions, the agreement is excellent. Observations suggest that in cirrus clouds, $\mathrm{RH}_{\text {ice }}$ is mostly below $120 \%$ (Haag et al., 2003), meaning the lower $\mathrm{RH}_{\text {ice }}$ values where the DSF works better are most relevant to observed cirrus clouds.

\section{Evaluation}

There are case studies investigating ice nucleation over Europe at specific locations, under a variety of atmospheric conditions. These observations were typically for only a few weeks at a time, so climatological time series of ice nuclei are not yet available. Observations presented in several recent studies (Chou et al., 2011; Conen et al., 2012; Joly et al., 2014; Klein et al., 2010) will be used to make a statistical comparison with the results presented here. DeMott et al. (2010) provide a best-fit function to a number of observations from outside Europe, which is used here as an additional evaluation tool. Figure 4 shows a 2-D histogram of normalised potential INP concentration in $0.5 \mathrm{~K}$ bins for the whole domain in July 2008. Overlaid on the figure are the observations from selected field studies, as well as the best fit suggested by DeMott et al. (2010). The temperatures of the observations are instrument temperatures, whereas the model INPs are calculated at the modelled ambient temperature in the grid box.

From Fig. 4, most immersion INPs are occurring at temperatures warmer than $250 \mathrm{~K}$, with concentrations typically less than $10^{2} \mathrm{~m}^{-3}$. The Niemand et al. (2012) parameterisation produces most of the INPs with concentrations a few orders of magnitude lower than DeMott et al. (2010) suggest. Almost all the observations fall within the range of the parameterised immersion INPs, and note that the observations from Klein et al. (2010) were taken during a Saharan dust outbreak resulting in higher than normal INP concentrations. The immersion parameterisation also shows a greater sensitivity to temperature than DeMott et al. (2010) indicate, however it is important to note that the best fit provided by these authors is dependant on aerosol composition, amongst other things. Observations at colder temperatures from Chou et al. (2011) fall in the middle of the range of concentrations given by the deposition nucleation parameterisation. Again, during Saharan dust events these observations indicate higher concentrations of INPs.

Most of the observed INPs are at temperatures warmer than the immersion parameterisation allows. According to Joly et al. (2014), most of the measured INPs are biological in origin. These INPs are not considered in this study. However, it is interesting to note that the parameterised dust INP concentrations agree well with the Joly et al. (2014) data at $260 \mathrm{~K}$. Most of the data from Conen et al. (2012) was also taken at temperatures warmer that $260 \mathrm{~K}$, indicating that dust can nucleate ice at temperatures warmer than the Niemand et al. (2012) parameterisation. Nevertheless, the concentrations are the same as the parameterisation at $260 \mathrm{~K}$.

The results from the immersion parameterisation suggest that high INP concentrations greater than $10^{6} \mathrm{~m}^{-3}$ are only produced at temperatures less than $250 \mathrm{~K}$, and only observations from during a Saharan dust event suggest concentrations this high. In addition to this, observations shown by DeMott et al. (2010) from the Pacific Dust Experiment suggest INP concentrations can reach over $10^{5} \mathrm{~m}^{-3}$ at $240 \mathrm{~K}$ in the condensation mode. DeMott et al. (2003) presents observations from aircraft measurements of INPs in an air mass which originated from North Africa. At temperatures above the homogeneous freezing threshold, INPs were present in 

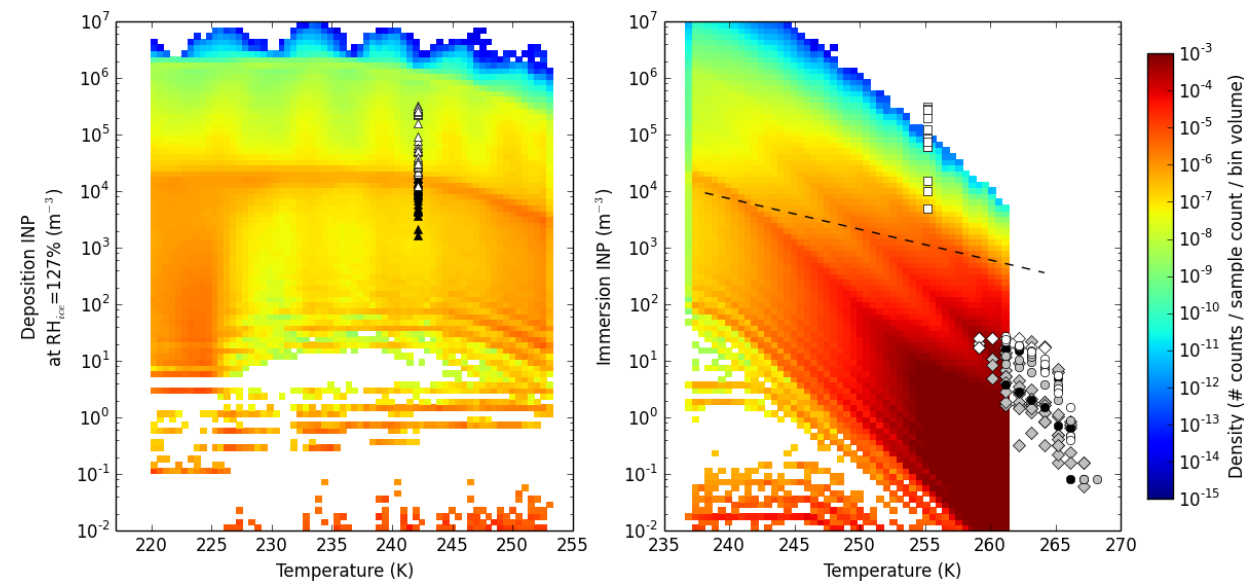

Figure 4. Left: normalised potential deposition INPs at $\mathrm{RH}_{\mathrm{ice}}=127 \%$. Right: normalised potential immersion INPs for July 2008, compared to observations. Observations are shown from Chou et al. (2011) (white triangles: Saharan dust event, black triangles: non-dust event), Conen et al. (2012) (black circles: dust from North Italy, grey circles: dust from North Africa/Switzerland, white circles: dust from Switzerland/South Germany), DeMott et al. (2010) (dashed line), Joly et al. (2014) (grey diamonds: within detection limit, white diamonds: at detection limit) and Klein et al. (2010) (white squares).

concentrations up to $10^{6} \mathrm{~m}^{-3}$. This implies that the INP concentrations presented here are in broad agreement with available observations.

\section{Conclusions}

The COSMO-MUSCAT model was used to simulate the generation and transport of Saharan desert dust to Europe during the period December 2007-August 2008. Maximum median dust concentrations are around $3 \times 10^{5} \mathrm{~m}^{-3}$ during spring, with about an order of magnitude lower number concentrations in summer. There is a significant amount of variability in dust concentrations. The resulting potential immersion INPs reach maximum median concentrations of $9.5 \times 10^{4} \mathrm{~m}^{-3}$ during spring. During the summer months concentrations are lower, and occur at a higher altitude compared to all other months. INP concentrations in the deposition mode for $\mathrm{RH}_{\text {ice }}$ of $110 \%$ increase exponentially and reach over $10^{5} \mathrm{~m}^{-3}$ in spring. At the coldest temperatures allowed by the deposition parameterisation, the trend in INP concentrations follow that of the dust number concentrations.

Since the median concentrations vary only slightly with latitude and longitude, the median vertical profiles of INP concentrations are representative of the background INP concentrations over the whole domain considered here. Therefore, using these results, a mathematical model is provided to estimate the INP concentrations as a function of temperature for immersion freezing, and as a function of temperature and $\mathrm{RH}_{\text {ice }}$ for deposition nucleation. The deposition scaling factor works best for values of $\mathrm{RH}_{\text {ice }}$ less than about $120 \%$. This can be applied to process studies and regional climate simulations over Europe wishing to include a realistic description of ice formed from immersion freezing and deposition nucleation on natural dust particles.

The new estimates of INP concentrations were compared to commonly used parameterisations for immersion freezing and deposition nucleation. The peak concentrations lie in the middle of a range of estimates from earlier parameterisations for immersion freezing, and for deposition nucleation they are smaller for warmer temperatures and larger for the coldest temperatures. The approach presented here captures a much more realistic vertical and seasonal variability, thus providing an extra level of utility for model simulations over Europe. A statistical evaluation with available observations indicates that the Niemand et al. (2012) and Steinke et al. (2014) parameterisations produce most of the INPs at similar concentrations to what the observations suggest, providing confidence in the results presented here.

Acknowledgements. The authors wish to thank Cedric Chou for kindly providing data used in the evaluation, and Axel Seifert for helpful discussions. This work was funded by the Federal Ministry of Education and Research in Germany (BMBF) through the research programme "High Definition Clouds and Precipitation for Climate Prediction - HD(CP) $)^{2 "}$ (FKZ: 01LK1204B).

The article processing charges for this open-access publication were covered by a Research Centre of the Helmholtz Association.

Edited by: M. C. Facchini 


\section{References}

Atkinson, J. D., Murray, B. J., Woodhouse, M. T., Whale, T. F., Baustian, K. J., Carslaw, K. S., Dobbie, S., O'Sullivan, D., and Malkin, T. L.: The importance of feldspar for ice nucleation by mineral dust in mixed-phase clouds, Nature, 498, 355-358, 2013.

Bangert, M., Nenes, A., Vogel, B., Vogel, H., Barahona, D., Karydis, V. A., Kumar, P., Kottmeier, C., and Blahak, U.: Saharan dust event impacts on cloud formation and radiation over Western Europe, Atmos. Chem. Phys., 12, 4045-4063, doi:10.5194/acp-124045-2012, 2012.

Boucher, O., Randall, D., Artaxo, P., Bretherton, C., Feingold, G., Forster, P., Kerminen, V.-M., Kondo, Y., Liao, H., Lohmann, U., Rasch, P., Satheesh, S. K., Sherwood, S., Stevens, B., and Zhang, X. Y.: Clouds and aerosols. in: Climate change 2013: The physical science basis, contribution of working group $i$ to the fifth assessment report of the intergovernmental panel on climate change. Intergovernmental Panel on Climate Change, Working Group I Contribution to the IPCC Fifth Assessment Report (AR5)(Cambridge Univ Press, New York), 2013.

Chou, C., Stetzer, O., Weingartner, E., Jurányi, Z., Kanji, Z. A., and Lohmann, U.: Ice nuclei properties within a Saharan dust event at the Jungfraujoch in the Swiss Alps, Atmos. Chem. Phys., 11, 4725-4738, doi:10.5194/acp-11-4725-2011, 2011.

Conen, F., Henne, S., Morris, C. E., and Alewell, C.: Atmospheric ice nucleators active $\leq-12{ }^{\circ} \mathrm{C}$ can be quantified on $\mathrm{PM}_{10}$ filters, Atmos. Meas. Tech., 5, 321-327, doi:10.5194/amt-5-321-2012, 2012

Cooper, W. A.: Ice initiation in natural clouds, Meteorol. Monogr., 21, 29-32, 1986.

Cozic, J., Mertes, S., Verheggen, B., Cziczo, D. J., Gallavardin, S., Walter, S., Baltensperger, U., and Weingartner, E.: Black carbon enrichment in atmospheric ice particle residuals observed in lower tropospheric mixed phase clouds, J. Geophys. Res.Atmos., 113, D15209, doi:10.1029/2007JD009266, 2008.

Cziczo, D. J., Froyd, K. D., Hoose, C., Jensen, E. J., Diao, M., Zondlo, M. A., Smith, J. B., Twohy, C. H., and Murphy, D. M.: Clarifying the dominant sources and mechanisms of cirrus cloud formation, Science, 340, 1320-1324, 2013.

DeMott, P. J., Sassen, K., Poellot, M. R., Baumgardner, D., Rogers, D. C., Brooks, S. D., Prenni, A. J., and Kreidenweis, S. M.: African dust aerosols as atmospheric ice nuclei, Geophys. Res. Lett., 30, 1732, doi:10.1029/2003GL017410, 2003.

DeMott, P. J., Prenni, A. J., Liu, X., Kreidenweis, S. M., Petters, M. D., Twohy, C. H., Richardson, M. S., Eidhammer, T., and Rogers, D. C.: Predicting global atmospheric ice nuclei distributions and their impacts on climate, Proc. Natl. Aca. Sci., 107, 11217-11222, 2010.

DeMott, P. J., Prenni, A. J., McMeeking, G. R., Sullivan, R. C., Petters, M. D., Tobo, Y., Niemand, M., Möhler, O., Snider, J. R., Wang, Z., and Kreidenweis, S. M.: Integrating laboratory and field data to quantify the immersion freezing ice nucleation activity of mineral dust particles, Atmos. Chem. Phys., 15, 393-409, doi:10.5194/acp-15-393-2015, 2015.

Fletcher, N. H.: The physics of rainclouds, Cambridge University Press, 386 pp., 1962.

Haag, W., Kärcher, B., Ström, J., Minikin, A., Lohmann, U., Ovarlez, J., and Stohl, A.: Freezing thresholds and cirrus cloud formation mechanisms inferred from in situ measurements of relative humidity, Atmos. Chem. Phys., 3, 1791-1806, doi:10.5194/acp3-1791-2003, 2003

Heinold, B., Tegen, I., Esselborn, M., Kandler, K., Knippertz, P., Müller, D., Schladitz, A., Tesche, M., Weinzierl, B., Ansmann, A., Althausen, D., Laurent, B., Massling, A., Müller, T., Petzold, A., Schepanski, K., and Wiedensohler, A.: Regional saharan dust modelling during the samum 2006 campaign, Tellus B, 61, 307324, 2009.

Heinold, B., Tegen, I., Schepanski, K., Tesche, M., Esselborn, M., Freudenthaler, V., Gross, S., Kandler, K., Knippertz, P., Müller, D., Schladitz, A., Toledano, C., Weinzierl, B., Ansmann, A., Althausen, D., Müller, T., Petzold, A., and Wiedensohler, A.: Regional modelling of saharan dust and biomass-burning smoke, Tellus B, 63, 781-799, 2011.

Heintzenberg, J., Okada, K., and Ström, J.: On the composition of non-volatile material in upper tropospheric aerosols and cirrus crystals, Atmos. Res., 41, 81-88, 1996.

Hiranuma, N., Paukert, M., Steinke, I., Zhang, K., Kulkarni, G., Hoose, C., Schnaiter, M., Saathoff, H., and Möhler, O.: A comprehensive parameterization of heterogeneous ice nucleation of dust surrogate: laboratory study with hematite particles and its application to atmospheric models, Atmos. Chem. Phys., 14, 13145-13158, doi:10.5194/acp-14-13145-2014, 2014.

Hoose, C. and Möhler, O.: Heterogeneous ice nucleation on atmospheric aerosols: a review of results from laboratory experiments, Atmos. Chem. Phys., 12, 9817-9854, doi:10.5194/acp-12-98172012, 2012.

Hoose, C., Kristjánsson, J., and Burrows, S.: How important is biological ice nucleation in clouds on a global scale?, Environ. Res. Lett., 5, 024009, doi:10.1088/1748-9326/5/2/024009, 2010.

Joly, M., Amato, P., Deguillaume, L., Monier, M., Hoose, C., and Delort, A.-M.: Quantification of ice nuclei active at near $0{ }^{\circ} \mathrm{C}$ temperatures in low-altitude clouds at the Puy de Dôme atmospheric station, Atmos. Chem. Phys., 14, 8185-8195, doi:10.5194/acp-14-8185-2014, 2014.

Kamphus, M., Ettner-Mahl, M., Klimach, T., Drewnick, F., Keller, L., Cziczo, D. J., Mertes, S., Borrmann, S., and Curtius, J.: Chemical composition of ambient aerosol, ice residues and cloud droplet residues in mixed-phase clouds: single particle analysis during the Cloud and Aerosol Characterization Experiment (CLACE 6), Atmos. Chem. Phys., 10, 8077-8095, doi:10.5194/acp-10-8077-2010, 2010.

Klein, H., Nickovic, S., Haunold, W., Bundke, U., Nillius, B., Ebert, M., Weinbruch, S., Schuetz, L., Levin, Z., Barrie, L. A., and Bingemer, H.: Saharan dust and ice nuclei over Central Europe, Atmos. Chem. Phys., 10, 10211-10221, doi:10.5194/acp10-10211-2010, 2010.

Lohmann, U. and Feichter, J.: Global indirect aerosol effects: a review, Atmos. Chem. Phys., 5, 715-737, doi:10.5194/acp-5-7152005, 2005.

Mamouri, R. E. and Ansmann, A.: Estimated desert-dust ice nuclei profiles from polarization lidar: methodology and case studies, Atmos. Chem. Phys., 15, 3463-3477, doi:10.5194/acp-15-34632015, 2015.

Meyers, M. P., DeMott, P. J., and Cotton, W. R.: New primary icenucleation parameterizations in an explicit cloud model, J. Appl. Meteorol., 31, 708-721, 1992. 
Murray, B., O'Sullivan, D., Atkinson, J., and Webb, M.: Ice nucleation by particles immersed in supercooled cloud droplets, Chem. Soc. Rev., 41, 6519-6554, 2012.

Niemand, M., Möhler, O., Vogel, B., Vogel, H., Hoose, C., Connolly, P., Klein, H., Bingemer, H., DeMott, P., Skrotzki, J., and Leisner, T.: A particle-surface-area-based parameterization of immersion freezing on desert dust particles, J. Atmos. Sci., 69, 3077-3092, 2012.

Phillips, V. T., DeMott, P. J., and Andronache, C.: An empirical parameterization of heterogeneous ice nucleation for multiple chemical species of aerosol, J. Atmos. Sci., 65, 2757-2783, 2008.

Pratt, K. A., DeMott, P. J., French, J. R., Wang, Z., Westphal, D. L., Heymsfield, A. J., Twohy, C. H., Prenni, A. J., and Prather, K. A.: In situ detection of biological particles in cloud ice-crystals, Nat. Geosci., 2, 398-401, 2009.

Prenni, A. J., Petters, M. D., Kreidenweis, S. M., Heald, C. L., Martin, S. T., Artaxo, P., Garland, R. M., Wollny, A. G., and Pöschl, U.: Relative roles of biogenic emissions and saharan dust as ice nuclei in the amazon basin, Nat. Geosci., 2, 402-405, 2009.

Sassen, K.: Indirect climate forcing over the western us from asian dust storms, Geophys. Res. Lett., 29, 103-1, doi:10.1029/2001GL014051, 2002.

Sassen, K., DeMott, P. J., Prospero, J. M., and Poellot, M. R.: Saharan dust storms and indirect aerosol effects on clouds: Crystal-face results, Geophys. Res. Lett., 30, 1633, doi:10.1029/2003GL017371, 2003.

Steinke, I., Hoose, C., Möhler, O., Connolly, P., and Leisner, T.: A new temperature- and humidity-dependent surface site density approach for deposition ice nucleation, Atmos. Chem. Phys., 15, 3703-3717, doi:10.5194/acp-15-3703-2015, 2015.
Steppeler, J., Doms, G., Schättler, U., Bitzer, H., Gassmann, A., Damrath, U., and Gregoric, G.: Meso-gamma scale forecasts using the nonhydrostatic model $\mathrm{lm}$, Meteorol. Atmos. Phys., 82, 75-96, 2003.

Targino, A. C., Krejci, R., Noone, K. J., and Glantz, P.: Single particle analysis of ice crystal residuals observed in orographic wave clouds over Scandinavia during INTACC experiment, Atmos. Chem. Phys., 6, 1977-1990, doi:10.5194/acp-6-1977-2006, 2006.

Tegen, I., Harrison, S. P., Kohfeld, K., Prentice, I. C., Coe, M., and Heimann, M.: Impact of vegetation and preferential source areas on global dust aerosol: Results from a model study, J. Geophys. Res.-Atmos., 107, 4576, doi:10.1029/2001JD000963, 2002.

Tegen, I., Schepanski, K., and Heinold, B.: Comparing two years of Saharan dust source activation obtained by regional modelling and satellite observations, Atmos. Chem. Phys., 13, 2381-2390, doi:10.5194/acp-13-2381-2013, 2013.

Todd, M. C., Bou Karam, D., Cavazos, C., Bouet, C., Heinold, B., Baldasano, J. M., Cautenet, G., Koren, I., Perez, C., Solmon, F., Tegen, I., Tulet, P., Washington, R., and Zakey, A.: Quantifying uncertainty in estimates of mineral dust flux: An intercomparison of model performance over the bodélé depression, northern Chad, J. Geophys. Res.-Atmos., 113, D24107, doi:10.1029/2008JD010476, 2008.

Wolke, R., Hellmuth, O., Knoth, O., Schröder, W., Heinrich, B., and Renner, E.: The chemistry-transport modeling system lmmuscat: Description and citydelta applications Air Pollution Modeling and Its Application XVI, Springer, 427-439, 2004. 